\title{
TATA LAKSANA E-PROCUREMENT DI KABUPATEN PANGKAJENE DAN KEPULAUAN
}

\author{
${ }^{1}$ Nur Ikhsan, ${ }^{2}$ Andi Nuraeni Aksa, ${ }^{3}$ Adnan Ma'ruf \\ 1) Jurusan Ilmu Administrasi Negara Fisip Unismuh Makassar \\ 2) Jurusan Ilmu Administrasi Negara Fisip Unismuh Makassar \\ 3) Jurusan Ilmu Administrasi Negara Fisip Unismuh Makassar
}

\begin{abstract}
The main purpose in this research is implementation understanding of E procurement also understand of supporting and E procurement obstacle factor in the pangkep district. E-procurement is an innovation in the use of Information Technology for the benefit of public services. Based on this, researchers are encouraged to try to explain the implementation of E-procurement in the Pangkep district. Amount of informan in this research are five people. type of research is qualitative with kind of fenomenology research which is focused on human living experiences. Collecting data technique are using observation method, interview and documentation. Data analysis using interactive analysis models. Research result refers to unoptimalitation of E procurement implementation in the Pangkep district. This implementation seen by the stage of the E procurement aspect altough appropriated absolutely unaccomplished. In accordance with the implementation exist in president regulation in article 107 year 2010 number 54. This can be seen indicator (1) E-tendering (2) E-bidding (3) Ecatalogue and(4) E-purchasing. Supporting factor in this implementation is strategy of loyalty provider whereas obstacles are divergents and postponement.
\end{abstract}

Key word: E-service, Job Fair, Pangkep Regency.

\begin{abstract}
ABSTRAK
Tujuan penelitian adalah untuk mengetahui Tata Laksana E-procurement dan mengetahui faktor pendukung dan penghambat E-procurement di Kabupaten Pangkajene dan Kepulauan. Eprocurement merupakan suatu inovasi dalam pemanfaatan Teknologi Informasi untuk kepentingan pelayanan publik. Berdasarkan hal tersebut peneliti terdorong untuk mencoba menjelaskan Pelaksanaan E-procurement di Kabupaten Pangkajene dan Kepulauan. Jumlah informan dalam penelitian ini adalah 05 orang. Jenis penelitian yang digunakan adalah kualitatif dengan tipe penelitian fenomenologi yaitu menekankan pada subyektivitas pengalaman hidup manusia. Teknik pengumpulan data menggunakan metode observasi, wawancara dan dokumentasi. Analisis data dengan menggunakan model analisa interaktif. Hasil penelitian menunjukkan bahwa Pelaksanaan Eprocurement di Kabupaten Pangkajene dan Kepulauan belum sepenuhnya terlaksana dengan optimal hal ini dilihat dari aspek tahapan E-procurement dimana penyedia yang meskipun telah sesuai dengan prosedur namun belum sepenuhnya berhasil dalam melaksanakan tahapan E-procurement sesuai dengan tujuan yang terdapat dalam Peraturan Presiden No. 54 tahun 2010 pasal 107. hal ini dilihat dari indikator (1) E-tendering (2) E-bidding (3) E-catalogue dan (4) E-purchasing. Faktor Pendukung dalam pelaksanaan ini adalah Strategi dan Loyalitas penyedia sedangkan faktor yang menjadi penghambat adalah penyimpangan dan penundaan.
\end{abstract}

Kata Kunci: Tata Laksana, E-Procurement, Kabupaten Pangkep. 


\section{PENDAHULUAN}

Tata Laksana diartikan sebagai proses ataupun cara mengurus dalam melaksanakan suatu kegiatan. Lebih jauh tentang Tata Laksana sebagai suatu proses yang dikatakan oleh Grindel, (dalam Handayaningrat 2002) menjelaskan bahwa proses implementasi baru dimulai apabila tujuan dan sasaran telah ditetapkan program kerja, telah disusun dan telah disiapkan dan disalurkan untuk pencapaian tujuan/sasaran tersebut.

Tata Laksana merupakan arti dari implementasi. Udoji (1981) dalam Mustari (2013:136) dengan tegas mengatakan bahwa the execution of policies is a importantif no more importent than policymaking. policies will remain dreams or blue prints file. jackets unless they are implemented (pelaksanaan kebijakan adalah Sesuatu yang penting, jauh lebih penting dari pembuatan kebijakan. Kebijakan akan sekedar impian atau rencana bagus yang tersimpan rapih dalam arsip kalau tidak di implementasikan. Arti lain pembuatan kebijakan tidak berakhir setelah kebijkan di tentukan atau di setujui).
Implementasi merupakan tindak lanjut dari suatu program yang ditetapkan berlaku dan dirumuskan. Dengan demikian fokus perhatian implementasi yakni kesediaan yang ditimbulkan sesudah disahkannya pedoman-pedoman kebijaksanaan ditetapkan. Van Meter dan Van Horn (1975) dalam Suratman (2017) mendefinisikan implementasi kebijakan publik sebagai tindakan-tindakan yang dilakukan oleh organisasi publik yang diarahkan untuk mencapai tujuan-tujuan yang telah ditetapkan dalam keputusan sebelumnya. Tindakan-tindakan ini mencakup usaha-usaha untuk mengubah keputusan-keputusan menjadi tindakan operasional dalam kurun waktu tertentu maupun dalam rangka melanjutkan usahausaha untuk mencapai perubahan besar dan kecil yang ditetapkan oleh keputusankeputusan kebijakan.

\section{Pengimplementasian suatu}

kebijakan tidak lepas dari suatu permasalahan yang menyebabkan kegagalan pencapaian tujuan kebijakan/program yang di implementasikan dapat diidentifikasi. Langkah selanjutnya adalah menentukan strategi untuk mengatasi kegagalan 
tersebut. Strategi yang dilakukan tentu sangat disesuaikan dengan tipe kegagalan implementasi program. Ada empat tipe implementasi sebuah kebijakan Goggin et, al (1990) dalam Erwan dan Dyah. Dalam hal ini faktor penghambat dan pendukung suatu kebijakan yakni: (1) Penyimpangan (defiance), (2) Penundaan (delay), (3) strategi (strategic), dan (4) loyalitas (loyality).

\section{E-Government merupakan} kependekan dari Electronic Government, atau ada yang menyebutnya dengan $E$ Gov. E-Government adalah salah satu bentuk atau model sistem pemerintahan yang berlandaskan pada kekuatan teknologi digital, di mana semua pekerjaan administrasi, pelayanan terhadap masyarakat, pengawasan dan pengendalian sumber daya milik organisasi yang bersangkutan, keuangan, pajak, retribusi, karyawan dan sebagainya dikendalikan dalam satu sistem.

Menurut Indrajit (2002) dalam Budi Rianto dkk (2012: 36): "Bahwa EGovernment merupakan suatu mekanisme interaksi baru antara pemerintah dengan masyarakat dan kalangan lain yang berkepentingan, dengan melibatkan penggunaan teknologi informasi (terutama internet) dengan tujuan memperbaiki mutu (kualitas) pelayanan". Pendapat yang ada, Budi Rianto dkk (2012:36) menyimpulkan bahwa E-Government merupakan bentuk aplikasi pelaksanaan tugas dan tatalaksana pemerintahan menggunakan teknologi telematika atau teknologi informasi dan komunikasi. Berdasarkan beberapa definisi yang disampaikan para ahli diatas, disimpulkan bahwa E-Government adalah sistem pemerintahan yang menggunakan teknologi informasi untuk memberikan pelayanan dan informasi bagi masyarakat dalam urusan bisnis serta hal penting lainnya yang berhubungan dengan pemerintahan.

E-Procurement merupakan bagian dari E-Government. E-Procurement berada pada model Government-toBusiness dimana dijelaskan bahwa pemerintah menyediakan informasi kepada para pelaku bisnis untuk mengikuti transaksi pengadaan barang dan jasa untuk membantu pemerintah dalam menunjang kerja-kerja organisasi, mulai dari perlengkapan di dalam kantor hingga perlengkapan lapangan. LKPP (Lembaga Kebijakan Pengadaan Barang/Jasa Pemerintah) mengatakan bahwa E-Procurement merupakan proses 
pengadaan barang dan jasa pemerintah yang dilakukan secara elektronik terutama berbasis web atau internet. Engstorm, et.al. (2009) mendefinisikan pengertian E-procurement adalah proses pengadaan barang dan jasa secara elektronik. Kodar Udoyono (2012) mengatakan bahwa pengadaan barang dan jasa tanpa $E$ Procurement telah mengakibatkan penyalahgunaan anggaran negara mencapai 10-50 persen. Maria Avilla dalam jurnalnya (2014:14) mengatakan penerapan E-Procurement berakibat pada terjadinya sejumlah pengurangan, mulai dari harga pembelian barang, waktu proses pembelian, penagihan, dan pembayaran, hingga pengurangan biaya administrasi maupun waktu dari proses pengadaan barang.

$$
\text { Kodar Udoyono }
$$

mengatakan kebijakan implementasi $E$ Procurement dilakukan dengan cara optimal pemanfaatan kemajuan teknologi informasi untuk mewujudkan good governance melalui pengadaan barang/jasa yang bebas KKN.

Undang-undang Nomor 11 Tahun 2008 tentang Informasi dan Transaksi Elektronik, bahwa pemanfaatan teknologi informasi berperan penting dalam perdagangan dan pertumbuhan perekonomian nasional untuk kesejahteraan masyarakat yang berdampak dalam meningkatkan efektivitas dan efisiensi pelayanan publik. Mengacu kepada Undang-undang Nomor 11 Tahun 2008 tersebut dan dalam rangka pemanfaatan perkembangan teknologi, maka Kementerian Sekretariat Negara telah mulai melaksanakan pengadaan barang/jasa secara elektronik atau $e$ procurement sejak tahun 2009.

\section{E-Procurement merupakan}

pengadaan barang/jasa yang dilakukan dengan menggunakan teknologi informasi dan transaksi elektronik sesuai dengan ketentuan perundang-undangan. Demikian definisi yang tercantum dalam Peraturan Presiden Nomor 54 Tahun 2010 tentang Pengadaan Barang/Jasa Pemerintah yang ditetapkan pada tanggal 6 Agustus 2010 kebijakan ini adalah kebijakan nasional, kemudian wajib dilaksanakan diseluruh kabupaten daerah di Indonesia terutama di Kabupaten Pangkajene dan Kepulauan itu di tahun 2012. Sementara pengertian Transaksi Elektronik yang tertulis dalam Undang-Undang Nomor 11 Tahun 2008 tentang Informasi dan Transasksi Elektronik yang diundangkan pada tanggal 
21 April 2008, adalah perbuatan hukum yang dilakukan dengan menggunakan komputer, jaringan komputer, dan/atau media elektronik lainnya. Dalam pasal 107 Peraturan Presiden Nomor 54 Tahun 2010 dijelaskan bahwa pengadaan barang/jasa pemerintah secara elektronik bertujuan untuk: (1) Meningkatkan transparansi dan akuntabilitas; (2) Meningkatkan akses pasar dan persaingan usaha yang sehat; (3) Memperbaiki tingkat efisiensi proses pengadaan; (4) Mendukung proses monitoring dan audit; dan (5) Memenuhi kebutuhan akses informasi yang real time.

Pengadaan barang/jasa secara elektronik ini dapat membuat segalanya menjadi lebih efisien, efektif, transparan, dan akuntabel. Namun, dibalik itu masih ada ketimpangan-ketimpangan yang menjadi alasan tidak berjalan efektifnya hal tersebut. Jika dikaitkan dengan TPK (Tindak Pidana Korupsi) maka akan sangat jelas masalah yang kemudian muncul pada pengadaan barang dan jasa. dibalik kecanggihan dalam pengadaan barang dan jasa melalui E-Procurement ada sisi lain yang harus diteliti secara komprehensif terutama di Kabupaten Pangkajene dan Kepulauan.
Sisi lain tersebut antara lain: (1) Pelaksanaan E-procurement selalu diincar dan tidak terlepas dari tindak pelanggaran oleh orang-orang yang tidak bertanggung jawab; dan (2) Pada tahap pelaksanaan $E$ procurement besar peluang panitia melakukan tindak pidana korupsi juga pelanggaran serta tindakan kolusi dan nepotisme antara panitia dengan penyedia barang yang ingin dimenangkan dan dipilih barang ataupun jasanya kepada konsumen yang membutuhkan. Beberapa bukti penelitian yang pernah ada setidaknya diperoleh 4 faktor kendala utama yaitu peraturan dan ketentuan hukum dalam memenuhi kebutuhan pelaksanaan E-Procurement, ditahap Tata Laksana dan pengaturan sistem pendukung E-Procurement, sosialisasi kepada pihak yang terlibat, dan unsur-unsur lain yang berpengaruh terhadap keberhasilan proses E-Procurement.

\section{METODE PENELITIAN}

Penelitian ini menggunakan pendekatan kualitatif dengan tipe fenomenologi. Untuk kebutuhan pengumpulan data, peneliti melakukan pengumpulan data primer yaitu data 
empiris yang diperoleh dari informan berdasarkan hasil wawancara. Adapun yang menjadi informan pada penelitian ini adalah Kepala Sub bagian Pelaksanaaan $E$ Procurement, Sub bagian Layanan Pengadaan Secara Elektronik, kepala Sub bagian Pembinaan E-procurement di kantor Bagian Layanan Pengadaan Barang dan Jasa di Kabupaten Pangkajene dan Kepulauan dan Pengguna E-Procurement (instansi) di kabupaten pangkajene dan kepulauan.

Data sekunder yang terdapat di dalam penelitian ini yaitu data yang dikumpulkan peneliti dari berbagai laporan-laporan atau bahkan dokumendokumen yang bersifat informasi tertulis yang digunakan dalam penelitian terkait $e$ service dalam bursa kerja di Dinas Tenaga Kerja dan Transmigrasi Kabupaten Gowa. Di dalam pengumpulan data yang digunakan teknik observasi, wawancara, dan dokumentasi dan dalam menganalisis data digunakan reduksi data, sajian data dan penarikan kesimpulan. Sedangkan untuk pengabsahan data digunakan tiga triangulasi yaitu triangulasi sumber, triangulasi waktu dan triangulasi teknik.

\section{HASIL DAN PEMBAHASAN}

Kabupaten Pangkajene dan Kepulauan adalah salah satu Kabupaten di Provinsi Sulawesi Selatan, dengan ibukotanya adalah Pangkajene secara administratif luas wilayah Kabupaten Pangkajene dan Kepulauan 12.362,73 $\mathrm{Km} 2$ (setelah diadakan analisis Bakosurtanal) untuk wilayah laut seluas $11.464,44 \mathrm{Km} 2$, dengan daratan seluas $898,29 \mathrm{Km} 2$, dan panjang garis pantai di Kabupaten Pangkajene, dan Kepulauan yaitu $250 \mathrm{Km}$, yang membentang dari barat ke timur. Di mana Kabupaten Pangkajene dan Kepulauan terdiri dari 13 kecamatan, di mana 9 kecamatan terletak pada wilayah daratan, dan 4 kecamatan terletak di wilayah kepulauan. Batas administrasi, dan batas fisik Kabupaten Pangkajene, dan Kepulauan adalah Sebelah Utara berbatasan dengan Kabupaten Barru, Sebelah Selatan berbatasan dengan Kabupaten Maros, Sebelah Timur berbatasan dengan Kabupaten Bone, Sebelah Barat berbatasan dengan Pulau Kalimantan, Pulau Jawa, dan Madura, Pulau Nusa Tenggara, dan Pulau Bali. Kabupaten Pangkajene, dan Kepulauan merupakan kabupaten yang struktur wilayah terdiri atas 2 bagian 
utama yang membentuk kabupaten ini yakni wilayah daratannya secara garis besar wilayah daratan Kabupaten Pangkajene, dan Kepulauan ditandai dengan bentang alam wilayah dari daerah dataran rendah sampai pegunungan, di mana potensi cukup besar juga terdapat pada wilayah daratan Kabupaten Pangkajene, dan Kepulauan yaitu ditandai dengan terdapatnya sumber daya alam berupa hasil tambang, seperti batu bara, marmer, dan semen.

Kemudian juga Wilayah kepulauan Kabupaten Pangkajene, dan Kepulauan merupakan wilayah yang memiliki kompleksitas wilayah yang sangat urgen untuk dibahas, wilayah kepulauan Kabupaten Pangkajene, dan Kepulauan memiliki potensi wilayah yang sangat besar untuk dikembangkan secara lebih optimal, untuk mendukung perkembangan wilayah Kabupaten Pangkajene, dan Kepulauan. Ada 25 dinas yang terdapat dan dikelola Kabupaten Pangkajene dan Kepulauan. Pada Peraturan bupati pangkajene dan kepulauan no.61 tahun 2017 bahwa kantor bagian layanan pengadaan dinaungi oleh sekretariat daerah serta diatasi oleh asisten perekonomian dan pembangunan, yang dimana terdapat pada pasal 17 a bahwa Bagian layanan pengadaan barang dan jasa dipimpin oleh seorang kepala bagian mempunyai tugas melaksanakan sebagian tugas asisten administrasi perekonomian dan pembangunan daklam merumuskan, melakukan koordinasi pembinaan, fasilitas, monitoring, serta evaluasi penyelenggaraan kegiatan dibidang pembinaan pengadaan, pelaksana pengadaan dan pengendalian pengadaan barang dan jasa.

Peraturan Presiden Nomor 54 Tahun 2010 tentang Pengadaan Barang/Jasa Pemerintah yang ditetapkan pada tanggal 6 Agustus 2010 kebijakan EProcurement adalah kebijakan nasional, kemudian wajib dilaksanakan diseluruh kabupaten/daerah yang ada diindonesia terutama dikabupaten pangkajene dan kepulauan itu di tahun 2012 Kantor bagian layanan pengadaan barang dan jasa berkedudukan di jalan poros pangkajenemakassar, tepatnya berada di Jl. Matahari No.1 kecamatan Pangkajene Kabupaten Pangkep yang memiliki aktifitas lalu lintas kendaraan yang cukup padat karena berseberangan dengan lapangan bola andi mappe. Kantor ini ialah merupakan setuan kerja perangkat daerah sebagai unsur 
pelaksana dalam penyelenggaraan pemerintahan daerah dibidang pengadaan barang dan jasa. Dipimpin oleh Kepala bagian yang berada di bawah dan bertanggung jawab langsung kepada Bupati sebagai kepala daerah. Kantor bagian layanan pengadaan barang dan jasa Kabupaten Pangkajene dan Kepulaian mempunyai tugas dalam pengadaan barang dan jasa secara elektronik yang dikhususkan untuk instansi yang ada di Kabupaten Pangkajene dan Kepulauan.

Visi "Menjadi pembaharuan yang kredibel untuk mewujudkan pengadaan yang menghasilkan Value for Money dalam rangka meningkatkan kesejahteraan masyarakat dan daya saing bangsa". Misi: Untuk mencapai visi tersebut dirumuskan ke dalam 3 (tiga) misi, yaitu: Mewujudkan pasar pengadaan yang efisien; Mendorong tumbuh dunia usaha yang berdaya saing Menjadi lembaga pembaharu yang inovatif dan berintegritas dalam pengadaan Bagian Layanan Pengadaan barang dsan jasa dipimpin oleh seorang kepala bagian yang mempunyai tugas melaksanakan sebagian tugas asisten administrasi perekonomian dan pembangunan dalam merumuskan, melakukan koordinasi, pembinaan, fasilitasi, monitoring serta evaluasi penyelenggaraan kegiatan dibidang pembinaan pengadaan, pelaksana pengadaan dan pengendalian pengadaan.

Sub bagian pembinaan pengadaan dipimpin oleh seorang kepala sub bagian mempunyai tugas melaksanakan sebagian tugas kepala bagian layanan pengadaan dalam penyiapan rumusan teknis perencanaan dan pelaksanaan pembinaan pengadaan barang dan jasa. Sub Bagian pelaksanaan pengadaan dipimpin oleh seorang kepala Sub Bagian mempunyai tugas melaksanakan sebagian tugas kepala bagian layanan pengadaan dibidang pelaksanaan pengadaan barang dan jasa. Sub Bagian pengendalian pengadaan barang dan jasa secara elektronik oleh seorang kepala Sub Bagian layanan pengadaan dalam penyiapan perumusan teknis dan pelaksanaan evaluasi pelaporan dan penyelesaian sanggah.

E-procurement merupakan sebuah inovasi dengan memanfaatkan perkembangan teknologi dan informasi dalam mengembangkan tata kelola sebuah instansi dalam pengadaan barang dan jasa di suatu daerah. Dalam Peraturan Presiden No.16 Tahun 2018 pasal 1 Pengadaan barang/jasa melalui penyedia adalah cara 
memperoleh barang/jasa yang disediakan oleh penyedia. Adapun data hasil pengadaan barang/ jasa menggunakan $E$ procurement dapat diakses di website resmi LPSE Kabupaten Pangkajene dan Kepulauan. Di Kabupaten Pangkajene dan Kepulauan khususnya di Kantor Bagian Layanan Pengadaan Barang dan Jasa mengadopsi inovasi pola pengadaan barang dan jasa ini (e-procurement) pada periode tahun 2012. E-procurement di Kabupaten Pangkajene dan Kepulauan ditinjau dari indikator (1) E-tendering, (2) E-bidding, (3) E-catalougue dan (4) Epurchasing.

E-Tendering adalah tata cara pemilihan pemasok yang dilakukan secara terbuka dan dapat diikuti oleh semua pemasok yang terdaftar pada sistem pengadaan secara elektronik. Pelaku usaha adalah setiap individu atau badan usaha, baik yang berbentuk badan hukum maupun bukan badan hukum yang didirikan dan berkedudukan atau melakukan kegiatan dalam wilayah hukum negara Republik Indonesia, baik sendiri maupun bersama-sama melalui perjanjian penyelenggaran kegiatan usaha dalam berbagai bidang ekonomi. Dalam pasal 17 dijelaskan bahwa penyedia wajib memenuhi kualifikasi sesuai dengan barang/jasa yang diadakan dan sesuai dengan ketentuan peraturan perundangundangan. Para pengguna jasa $e$ procurement sangat antusias dan cukup senang dengan adanya sistem ini karena memiliki pemahaman yaitu bertujuan akuntabel, efektif dan efisien dan menguntungkan bagi instansi yang bersangkutan. Hal tersebut sesuai dengan hasil observasi peneliti dilapangan yang menemukan bahwa hal yang disebutkan diatas sesuai dengan yang peneliti amati. Kemudian kesimpulan secara keseluruhan berkaitan dengan indikator E-tendering ini dapat dipahami bahwa dengan adanya inovasi pengadaan barang dan jasa seperti saat ini yang dulunya manual menjadikan hal ini dapat lebih mudah, efektif dan efisien serta bersifat akuntabel. Selanjutnya dari pihak pemasok hingga pengguna layanan e-procurement ini cukup merasa senang dan antusias dalam mengikuti dan memasarkan barang dan jasa yang ditawarkan.

E-bidding merupakan pelaksanaan pengadaan barang dan jasa dengan cara penyampaian informasi atau data pengadaan dari penyedia barang dan jasa, dimulai dari pengumuman sampai dengan 
pengumuman hasil pengadaan, yang dilakukan dengan media elektronik antara lain menggunakan media internet, intranet dan electronic data. Untuk mendapatkan informasi tentang kebutuhan yang diinginkan, maka pihak konsumen hanya mengakses informasinya diaplikasi sistem. Hal tersebut kurang sesuai dengan hasil observasi peneliti dilapangan yang menemukan bahwa hal yang disebutkan diatas kurang sesuai dengan yang peneliti amati. Kemudian kesimpulan secara keseluruhan berkaitan dengan indikator $E$ bidding ini dapat dipahami bahwa dengan adanya inovasi pengadaan barang dan jasa seperti saat ini, penyampaian informasi barang dan jasa yang ingin diketahui oleh penyedia maupun konsumen sangat mudah yang hanya mengakses informasi berupa barang dan jasa ke aplikasi SIRUP (Sistem Rencana Unit Pengadaan) tersebut mulai dari tahap awal hingga tahap evaluasi hasil pemenang. E-Catalogue adalah sistem informasi elektronik yang memuat daftar, jenis, spesifikasi teknis dan harga barang tertentu dari berbagai penyedia barang dan jasa. Pihak pengguna mengakses informasi berdasarkan aturan yang ditetapkan pemerintah di dalam aplikasi sistem itu sendiri karena kebijakan ini terfokuskan di gunakan oleh instansi pemerintah. Hal tersebut sesuai dengan hasil observasi peneliti dilapangan yang menemukan bahwa hal yang disebutkan diatas sesuai dengan yang peneliti amati.

Kemudian kesimpulan secara keseluruhan berkaitan dengan indikator $E$ catalogue ini dapat dipahami bahwa dengan adanya langkah ini sistem informasi elektronik mulai dari daftar jenis,spesifikasi teknis dan harga barang selalu disiapkan oleh panitia membuat penyedia ataupun konsumen dapat mengakses informasi dengan merasa aman, mudah, baik dan tepat karena Adanya aturan yang telah ditetapkan oleh pemerintah diaplikasi sistem itu sendiri.

E-Purchasing adalah tata cara pembelian (transaksi) barang dan jasa melalui sarana E-catalogue. Instansi terkait wajib mendukung mulai dari tahap awal hingga ditahap evaluasi terakhir pengumuman pemenang. Hal tersebut kurang sesuai dengan hasil observasi peneliti dilapangan yang menemukan bahwa hal yang disebutkan diatas kurang sesuai dengan yang peneliti amati. Kemudian kesimpulan secara keseluruhan berkaitan dengan indikator E-purchasing ini dapat dipahami bahwa dalam tahap 
awal hingga sampai tahap akhir (transaksi) kantor bagian pengadaan barang dan jasa wajib mendukung. Dalam segi keamanan juga penyedia maupun konsumen merasa aman karena pengadaan barang dan jasa ini dilegalitaskan pemerintah, apabila ada kesalahan maka itu sudah menjadi tanggung jawab pemerintah.

\section{Terlaksananya E-procurement} dengan baik dan maksimal di Kabupaten Pangkajene dan Kepulauan yang bertujuan agar semakin memudahkan tata kelola pengadaan suatu barang yang dipengaruhi oleh keberadaan faktor pendukung dan faktor penghambat. Di dalam hal ini yang menjadi indikator dalam faktor pendukung ialah (1) Strategi dengan (2) Ketaatan sedangkan indikator dari faktor penghambat yaitu (1) Penyimpangan dengan (2) Penundaan. Berkaitan dengan indikator strategi dapat dipahami dan disimpulkan bahwa untuk memenangkan dan dipilih oleh konsumen dan panitia, penyedia harus melengkapi syarat datanya dengan cepat dan juga tepat sesuai kebutuhan konsumen. Kemudian juga kesimpulan secara keseluruhan berkaitan dengan indikator ini dapat dipahami bahwa penyedia yang akan terpilih dan memenangkan hasil harus melengkapi syarat yang diinginkan oleh konsumen dan juga menjalankan syarat yang telah ditetapkan oleh konsumen disetiap Tahap yang diinginkan panitia.

Loyal yaitu tipe implementasi di mana implementor menjalankan implementasi tanpa disertai dengan perubahan (setia) terhadap isi dan mekanisme implementasi kebijakan tersebut. Pemerintah dalam hal ini panitia pengadaan barang dan jasa harus melakukan sosialisasi tentang syarat dan aturan disetiap tahapan pelaksanaan $E$ procurement khusus kepada penyedia demi menghindari terjadinya penyimpangan, penundaan dan pelanggaran lainnya. Kemudian kesimpulan secara keseluruhan berkaitan dengan indikator ini dapat dipahami bahwa ketaatan pada aturan yang telah ditetapkan oleh pemerintah dalam hal ini panitia pengadaan barang dan jasa secara elektronik harus diketahui dan laksanakan oleh setiap penyedia ataupun juga konsumen. Panitia pengadaan barang dan jasa harus melakukan sosialisasi tentang syarat dan aturan disetiap tahapan pelaksanaan E-procurement terkhusus kepada penyedia demi menghindari terjadi 
penyimpangan, penundaan dan pelanggaran lainnya.

Tipe implementasi ini diwarnai dengan terjadinya pengunduran atau bahkan sampai terjadinya pembatalan implementasi oleh implementer yang disertai perubahan-perubahan, baik tujuan, kelompok sasaran maupun mekanisme implementasi, yang berakibat tidak tercapainya tujuan. berkaitan dengan penyimpangan dapat dipahami dan disimpulkan bahwa penyimpangan terjadi tergantung dari situasi dan kondisi yang ada didalam tahap-tahap pelaksanaan $E$ procurement. Lalu kesimpulan secara keseluruhan berkaitan dengan indikator ini dapat dipahami bahwa penyimpangan dalam E-procurement dapat terjadi dalam setiap tahap pelaksanaan yang dimulai dari tahap perencanaan awal sampai ditahap akhir penentuan pemenang tergantung dari situasi dan kondisi yang ada. Dalam setiap tahap banyak kemungkinan bisa terjadi pelanggaran seperti korupsi, kolusi antara panitia pengadaan dengan penyedia barang, dan juga nepotisme. Penundaan (delay) yaitu penundaan tanpa modifikasi. Dalam kasus ini implementer menunda pelaksanaan implementasi, namun tidak sampai melakukan perubahan-perubahan terhadap isi kebijakan. Berkaitan dengan penundaan dapat dipahami dan disimpulkan bahwa penundaan keikutsertaan penyedia banyak terjadi ditahap awal karena menganggap barang yang disediakan kurang lengkap dari saingan penyedia yang lain. Kemudian kesimpulan secara keseluruhan berkaitan dengan indikator ini dapat dipahami bahwa penundaan keikutsertaan penyedia banyak yang terjadi ditahap awal karena menganggap barang yang disediakan kurang lengkap dari saingan penyedia yang lain. Tidak terlepasa pada tahap awal penundaan juga biasa terjadi ditahap akhir. Penundaan ditahap akhir dilakukan oleh penyedia karena alasannya adalah adanya tingkat kolusi yang diminta oleh panitia dan tak sanggup dipenuhi oleh penyedia yang telah memenangkan tahap penentuan tersebut.

Faktor pendukung pelaksanaan $E$ procurement di Kabupaten Pangkajene dan Kepulauan adalah unsur (a) penyimpangan dikarenakan penyedia akan terpilih dan memenangkan hasil harus melengkapi syarat yang diinginkan oleh konsumen dan juga menjalanka syarat disetiap Tahap yang diinginkan panitia. (b) ketaatan pada 
aturan yang telah ditetapkan oleh pemerintah dalam hal ini panitia pengadaan barang dan jasa secara elektronik harus diketahui dan laksanakan oleh setiap penyedia ataupun juga konsumen. Panitia pengadaan barang dan jasa harus melakukan sosialisasi tentang syarat dan aturan disetiap tahapan pelaksanaan E-procurement khusus kepada penyedia demi menghindari terjadi penyimpangan, penundaan dan pelanggaran lainnya. Sedangkan yang menjadi faktor penghambat ialah adanya (a) penyimpangan yang dapat terjadi dalam setiap tahap pelaksanaan yang dimulai dari tahap perencanaan awal sampai ditahap akhir penentuan pemenang tergantung dari situasi dan kondisi yang ada. Dalam setiap tahap banyak kemungkinan bisa terjadi pelanggaran seperti korupsi, kolusi antara panitia pengadaan dengan penyedia barang, dan juga nepotisme. (b) pada penundaan keikutsertaan penyedia banyak terjadi pada tahap awal karena menganggap barang ataupun jasa yang disediakan kurang lengkap dari saingan penyedia yang lain. Tidak terlepas pada tahap awal penundaan juga biasa terjadi ditahap akhir.
Penundaan ditahap akhir dilakukan oleh penyedia karena alasan adanya tingkat kolusi yang diminta oleh panitia dan tak sanggup dipenuhi oleh penyedia yang telah memenangkan tahap penentuan pengadaan barang dan jasa tersebut.

\section{KESIMPULAN}

Tata Laksana E-procurement dikabupaten pangkajene dan kepulauan secara umum terlaksana cukup baik, terlepas dari beberapa kekurangan di dalam proses pelaksanaannya. Dilihat dari (1) E-tendering, dengan adanya inovasi pengadaan barang dan jasa seperti ini yang dulunya manual menjadikan lebih mudah, efektif dan efisien bersifat akuntabel. (2) E-bidding yaitu penyampaian informasi atau data pengadaan dari panitia menjalankan kewajibannya telah sesuai dengan prosedur dan standar yang berlaku namun sedikit mengalami hambatan dalam memaksimalkan penyampaian informasi karena di setiap tahap pelaksanaan pengadaan tidak terlepas dari peluang pelanggaran $\mathrm{KKN}$ oleh panitia ataupun penyedia barang. (3) E-catalogue adalah tahapan ketiga pada sistem informasi elektronik mulai dari daftar jenis, spesifikasi teknis dan harga barang selalu 
disiapkan oleh panitia membuat penyedia ataupun konsumen dapat mengakses informasi dengan merasa aman, mudah, baik dan tepat karena Adanya aturan yang telah ditetapkan oleh pemerintah. (4) $E$ purchasing merupakan tahap transaksi. dalam tahap awal hingga tahap akhir (transaksi) kantor bagian pengadaan barang dan jasa wajib mendukung penyedia dengan konsumen. Faktor pendukung pelaksanaan E-procurement ini adalah unsur (a) penyimpangan dikarenakan penyedia akan memenangkan hasil harus melengkapi syarat yang diinginkan oleh konsumen dan panitia. (b) ketaatan pada aturan yang telah ditetapkan oleh pemerintah dalam hal ini panitia pengadaan barang dan jasa secara elektronik harus diketahui dan terlaksana.

\section{DAFTAR PUSTAKA}

Engstorm, Anne et. al.. (2009). "Implementation of Public EProcurement in

Swedish Government Entities". Proceedings of the International Multiconference on Computer Science and Information Technology.

Handayani Ningrat. 2002. Admnistrasi Pemerintahan Dalam Pembagunan Nasional. Jakarta: CV. Haji Mas Agung.
Indrajit, Richardus, Eko. 2002. Electronic Government: Strategi Pembangunan dan Pengembangan Sistem Pelayanan Publik Berbasis Teknologi Digital. Yogyakarta: Penerbit Andi.

Mustari, Nuryanti.2013. Implementasdi kebijakan publik, Pemahaman teoritis Empiris.Makassar: Membumi Publishing.

Peraturan Presiden No. 54 Tahun 2010 Tentang Pengadaan Barang/ Jasa Pemerintah.

Rianto, Budi., Tri Lestari. 2012. Polri \& Aplikasi E-Government dalam Pelayanan Publik. Surabaya: CV. Putra Media Nusantara (PMN).

Siagian, Sondang (2008). Manajemen Sumber Daya Manusia (Cetakan 15). Jakarta: Bumi Aksara

Sugiyono, 2014. Metode Penelitian Kuantitatif Kualitatif $R \quad \& \quad D$. Bandung: Alfabeta

Suratman. 2017. Generasi Implementasi dan Evaluasi Kebijakan Publik. Makassar: Copiya Publishing.

Wahab, Solichin Abdul. 2012. Analisis Kebijakan dari formulasi ke penyusun Model-model Implementasi Kebijakan Publik. Jakarta: Bumi Aksara.

Winarno, 2012. Teori dan Proses Kebijakan Publik. Yogyakarta: Media Pressindo. 